\title{
Role of Serum Amyloid A Protein in the Early Detection of Late Onset Sepsis in Neonate
}

\author{
Heba M. Abd Elkhalek ${ }^{\mathrm{a}}$, Neeven T Abed ${ }^{\mathrm{a}}$, Omima M. Abdel Haie ${ }^{\mathrm{a}}$, Seham Goda ${ }^{\mathrm{b}}$
}

\begin{abstract}
${ }^{\mathrm{a}}$ Department of pediatric, Benha faculty of medicine, Benha University, Egypt. ${ }^{\mathrm{b}}$ Department of Clinical and Chemical Pathology Faculty of Medicine, Benha University, Egypt.

Correspondence to: Heba M. Abd Elkhalek department of pediatric, faculty of medicine, Benha University, Egypt email: ayman8080@hotmail.com
\end{abstract} Received: 27 October 2019 Accepted: 2 November 2019

\begin{abstract}
:
Background: Late onset sepsis (LOS) is an important cause of serious illness and deaths among neonates. Diagnosis of neonatal sepsis remains a challenge owing to nonspecific early clinical signs and the non-availability of a reliable biomarker. Serum amyloid A (SAA), the precursor protein in inflammation-associated reactive amyloidosis, whose level in the blood increases up to 1000 fold in response to inflammation and it is also an acute phase reactant like PCT and CRP. Objectives: assessing the accuracy and rapidity of SAA in detection of LOS in neonates. Method: This is a case-control study which was carried out on neonates admitted in (NICU) of Benha University Hospital and Benha Teaching Hospital during the period (from June 2018 to November 2019). Group 1 (patients group): 45 neonates with neonatal sepsis, group 2
\end{abstract} (control group): 40 healthy neonates age and sex matched. SAA was measured. Results: mean value of SAA in septic group was $38.8 \mu \mathrm{g} / \mathrm{ml}$ compared to $1.26 \mu \mathrm{g} / \mathrm{ml}$ in control group , with statistically significant increase in patients than controls $(p<0.001)$. ROC curve was done to show the performance of SAA in the prediction of LOS. It was found that at a cut-off value of SAA $\geq 2.8 \mu \mathrm{g} / \mathrm{ml}$, SAA had a sensitivity $86.7 \%$, specificity $85 \%$, PPV $86.7 \%$, and NPV $85 \%$ for early diagnosis of LOS. At a cut-off value of SAA $\geq 45.2 \mu \mathrm{g} / \mathrm{ml}$, SAA had a sensitivity $83.3 \%$, specificity $69.7 \%$, PPV $50 \%$, and NPV $92 \%$ for the prediction of mortality among LOS patients. Conclusion: The high sensitivity, specificity, positive predictive value and negative predictive value of SAA protein could help the clinicians for early diagnosis of LOS.

Key words: Serum Amyloid A, Late Onset neonatal Sepsis, diagnosis. 


\section{Introduction:}

Neonatal sepsis is defined as a clinical syndrome in an infant 28 days of life or younger, manifested by systemic signs of infection and isolation of a bacterial pathogen from the bloodstream (1). The gold standard test for determining whether a newborn has sepsis or not is culturing body fluids such as blood or cerebral spinal fluid, but these cultures take up to $72 \mathrm{~h}$ (2).

Late onset sepsis (LOS) is an important cause of serious illness and death among premature infants, despite progress in the management and intensive supportive care of these neonates. Successful treatment depends on the early initiation of appropriate antibiotic therapy. (3).

The early and efficient diagnosis of neonatal sepsis in high risk neonates remains a difficult task, as the clinical signs are non-specific. If treatment is delayed till symptoms and signs of sepsis become obvious, the risk of preventable mortality would be brought up (4).

Blood culture has been commonly used as a traditional approach for the detection of sepsis. However, blood cultures are timeconsuming and at least 2-5 days of culture is necessary to identify the organism in the blood. Moreover, the sensitivity of blood cultures declines significantly if antibiotic therapy has been initiated, or when fastidious or slow growing pathogens are cultured. Therefore, other test, is done along with the blood culture to determine sepsis (5).

Serum amyloid A (SAA), the precursor protein in inflammation-associated reactive amyloidosis, whose level in the blood increases up to 1000 fold in response to inflammation, is synthesized in the liver. SAA is also an acute phase reactant like PCT and CRP (6).

This study aimed to assess the accuracy and rapidity of Serum Amyloid A in the detection of late onset sepsis in neonates

\section{Patients and Methods:}

Patients:

This case-control study was carried out on neonates admitted in neonatal intensive care unit (NICU) of Benha University Hospital and Benha Teaching Hospital during the period from June 2018 to August 2019.

Inclusion Criteria:

Neonates admitted to Neonatal intensive care unit (NICU) with signs and symptoms suggestive of late onset neonatal sepsis.

\section{Exclusion Criteria:}

- Patients less than 28 weeks of gestation.

- Patients with EOS.

- Patients with intra-ventricular hemorrhage (IVH) 
- Patients with hypoxic ischemic encephalopathy (HIE).

- Patients with life threatening congenital anomalies.

- Patients with hepatic dysfunctions.

Classification of neonates Included in the Study:

They were divided into two groups:

- Group 1 (patients' group): 45 neonates with clinical signs and symptoms suggestive of neonatal sepsis after the first week post- natal.

- Group 2 (control group): 40 healthy neonates age and sex matched.

Methods:

Data collection from the records of neonatal Sepsis cases in Neonatal Intensive Care Unit (NICU) of Benha teaching and Benha university hospitals, these data included:

Full medical history taking (to detect risk factors for sepsis):

- Age.

- Sex.

- Gestational age.

- Obstetric history (previous sibling death, previous admission to NICU, etc.).

- Prenatal history (diabetes mellitus, maternal fever $>38^{\circ} \mathrm{C}, \quad$ maternal antibiotics, maternal UTI, etc.)
- Natal history (PROM, maternal fever, prolonged 2nd stage of labor, etc.).

- Postnatal history (low Apgar score at 1 and 5 minutes, aggressive resuscitation, respiratory distress, cyanosis, fever, jaundice, etc.).

- Present history which includes most common symptoms of sepsis.

Thorough Clinical examination:

- Gestational age assessment.

- Birth weight measurement.

- Vital signs: heart rate, respiratory rate, temperature and blood pressure.

- Detection of clinical signs of sepsis:

- The infant is not doing well or going off, restlessness, lethargy, pallor and mottled skin.

- Temperature changes: hypothermia or hyperthermia.

- Respiratory dysfunction (apnea, signs of respiratory distress).

- Circulatory dysfunction (poor peripheral circulation, hypo-tension, prolonged capillary refill).

- GIT dysfunction (abdominal distension, feeding intolerance, hepatomegally and jaundice).

- Neurological dysfunction (irritability, hypotonia, lethargy, poor reflexes). 
- Sclerema: this is a late feature of any serious illness especially in preterm neonates $(7)$

Laboratory investigations include:

\section{- $C B C$}

Was done for all samples using sysmex KX-21N (Sysmex Corporation, New York, USA) for red blood cell (RBC) count, hemoglobin level, hematocrit value, WBC count (total and differential), and platelet count.

\section{- $\quad C R P$}

Estimation was carried out using the test kit (Cromatest) at 0h of clinical presentation. The AVITEX- CRP latex particles are coated with antibodies to human CRP. When the latex suspension is mixed with serum containing elevated CRP levels on a slide, clear agglutination was seen within 2 minutes. Specimen collection and storage: Fresh sample of venous blood was allowed to clot form and retract centrifuge clotted blood sample and collect serum, store at 2$8^{\circ} \mathrm{C}$ AVITEX-CRP had a detection limit of $6 \mathrm{mg} / \mathrm{L}$ of CRP in the patient's serum.

\section{- Blood culture}

- Serum amyloid A using ELISA kits.

Preface this ELISA kit is based on the principle of double-antibody sandwich technique to detect Human Serum amyloid A (SAA).

Test principle the kit uses a doubleantibody sandwich enzyme-linked immunosorbent assay (ELISA) to assay the level of Human Serum amyloid A (SAA)in samples. Serum amyloid A (SAA) was added to monoclonal antibody Enzyme well which was pre-coated with Human Serum amyloid A (SAA)monoclonal antibody, incubation. Then, SAA antibodies was added labeled with biotin, and combined with Streptavidin-HRP to form immune complex; then incubation and washing was carried again to remove the uncombined enzyme. Then Chromogen Solution A, B, were added the color of the liquid changed into the blue, then by the effect of acid, the color finally became yellow. The chroma of color and the concentration of the Human Substance Serum amyloid A (SAA) of sample were positively correlated.

Statistical analysis

The collected data were tabulated and analyzed using SPSS version 16 software (SpssInc, Chicago, ILL Company). Categorical data were presented as number and percentages. Chi square test $\left(\mathrm{X}^{2}\right)$, or Fisher's exact test (FET) were used to analyze categorical variables. Quantitative data were tested for normality using Kolomogrov Smirnove test assuming normality at $\mathrm{P}>0.05$. Quantitative data 
were expressed as mean \pm standard deviation, median and range. Student " $t$ " test was used to analyze normally distributed variables among 2 independent groups, or Mann Whitney $\mathrm{U}$ test for nonparametric ones. Difference among 3 independent means was analyzed using ANOVA for parametric variables or Kruskal Wallis test (KWT) for nonparametric ones. Spearman's correlation coefficient (rho) was used to assess correlation between non parametric variables. ROC curve was used to detect cutoff values with optimum sensitivity and specificity. The accepted level of significance in this work was stated at 0.05 ( $p<0.05$ was considered significant).

\section{Results:}

- There was no statistically significant difference between cases and control group regarding maternal age (ys), neonatal age (days), sex, mode of delivery and prenatal risk factors. There was statistically significant decrease in gestational age (w) and birth weight $(\mathrm{kg})$ among cases than controls (Table 1).

- Regarding temperature, fever and hypothermia were found in $22.2 \%$ and $13.3 \%$ respectivelly. Regarding mottling (48.9\%), petechiae (6.7\%), jaundice $(35.6 \%)$, regarding moro reflex, $28.9 \%$ had intact reflex and $71.1 \%$ had weak reflex. Regarding suckling, $20 \%$ and 80 $\%$ had good and poor suckling respectively, normal tone, hypotonia and hypertonia was detected in $73.3 \%, 20 \%$ and $6.7 \%$ respectively. $13.3 \%$ had convulsions, $97.8 \%$ had RD, $97.8 \%$ required $\mathrm{O} 2$. The folloing was detected: Lethargy (60\%), abdominal distension (13.3\%), feeding intolerance (57.8\%), HSM (22.2\%) (Table 2).

- There was statistically significant increase in blood glucose $(\mathrm{mg} / \mathrm{dl})$, WBCs $\left(\times 10^{3}\right)$, Total neutrophils , immature neutrophils, I/T ratio and serum amyloid A among cases than controls. There was statistically significant decrease in $\mathrm{Hb}(\mathrm{gm} / \mathrm{dl})$ and PLTs $\left(\times 10^{3}\right)$ among cases than controls (Table 3).

- regarding culture, no growth was $22.2 \%$, regarding gram positive, CONS was $13.3 \%$ and Staph aureus, GPS, MRSA were found in $6.7 \%, 8.9 \%$, $6.7 \%$ respectively. Regarding gram negative Klebsiella was observed in $17.8 \%$ and E Coli, Pseudomonas, Acinetobacter were found in $6.7 \%, 15.6$ $\%, 2.2 \%$ respectively (Table 4 ).

- There were highly statistically significant differences $\quad(p<0.001)$ between cases and the control group regarding death (Table 5). 
- Regarding performance of amyloid A in prediction of late onset sepsis, the Sens $\%$ was $86.7 \%$, Spec\% was $85 \%$,

- There was a statistically significant increase in serum amyloid A among dead than survived (Table 6). positive prediction value was $86.7 \%$, negative prediction value was $85 \%$ and the accuracy was $85.9 \%$, AUC

Table (1):

\begin{tabular}{|c|c|c|c|c|c|c|c|c|}
\hline \multirow[t]{2}{*}{ Variable } & \multicolumn{3}{|c|}{$\begin{array}{c}\text { Cases group } \\
\qquad(\mathbf{N}=\mathbf{4 5})\end{array}$} & \multicolumn{3}{|c|}{$\begin{array}{l}\text { Control group } \\
\qquad(\mathrm{N}=\mathbf{4 0})\end{array}$} & \multirow[t]{2}{*}{$\begin{array}{l}\text { St."t"' } \\
\text { test }\end{array}$} & \multirow[t]{2}{*}{$p$} \\
\hline & Mean & \pm SD & Range & Mean & \pm SD & Range & & \\
\hline Maternal age (ys) & 28.4 & 4.72 & $20-38$ & 27.8 & 4.06 & $21-37$ & 0.57 & 0.579 (NS) \\
\hline Gestational age (w) & 35.4 & 2.30 & $30-40$ & 36.7 & 1.97 & $32-39$ & 2.64 & $0.01(\mathrm{~S})$ \\
\hline Birth weight (kg) & 2.54 & 0.63 & $1.43-3.6$ & 2.85 & 0.47 & $2-3.95$ & 2.55 & $0.013(\mathrm{~S})$ \\
\hline \multirow[t]{2}{*}{ Age (days) } & 9.5 & 4.1 & $2-20$ & 8.2 & 4.2 & $4-19$ & $1.83 *$ & $0.067(\mathrm{NS})$ \\
\hline & & No. & $\%$ & No. & $\%$ & & $X^{2}$ & $p$ \\
\hline \multirow[t]{2}{*}{ Sex } & Male & 30 & 66.7 & 20 & 50.0 & & 2.42 & $0.12(\mathrm{NS})$ \\
\hline & Female & 15 & 33.3 & 20 & 50.0 & & & \\
\hline \multirow[t]{2}{*}{ Mode of delivery } & NVD & 10 & 22.2 & 12 & 30.0 & & 0.67 & $0.41(\mathrm{NS})$ \\
\hline & CS & 35 & 77.8 & 28 & 70.0 & & & \\
\hline \multirow[t]{2}{*}{ Prenatal risk factors } & Yes & 2 & 4.4 & 0 & 0.0 & & FET $^{*}$ & 0.49 (NS) \\
\hline & No & 43 & 95.6 & 40 & 100.0 & & $*$ & \\
\hline
\end{tabular}

*Mann Whitney U test, FET $^{* *}=$ Fisher's exact test 
Table (2):

\begin{tabular}{|c|c|c|c|}
\hline \multicolumn{2}{|c|}{ Variable } & No. $(\mathrm{N}=45)$ & $(100 \%)$ \\
\hline \multirow{3}{*}{ Temperature } & Normal & 29 & 64.4 \\
\hline & Fever & 10 & 22.2 \\
\hline & Hypothermia & 6 & 13.3 \\
\hline \multirow{2}{*}{ Mottling } & Yes & 22 & 48.9 \\
\hline & No & 23 & 51.1 \\
\hline \multirow{2}{*}{ Petechiae } & Yes & 3 & 6.7 \\
\hline & No & 42 & 93.3 \\
\hline \multirow{2}{*}{ Jaundice } & Yes & 16 & 35.6 \\
\hline & No & 29 & 64.4 \\
\hline \multirow{2}{*}{ Moro reflex } & Intact & 13 & 28.9 \\
\hline & Weak & 32 & 71.1 \\
\hline \multirow{2}{*}{ Suckling } & Good & 9 & 20.0 \\
\hline & Poor & 36 & 80.0 \\
\hline \multirow{3}{*}{ Tone } & Normal & 33 & 73.3 \\
\hline & Hypotonia & 9 & 20.0 \\
\hline & Hypertonia & 3 & 6.7 \\
\hline \multirow{2}{*}{ Convulsions } & Yes & 6 & 13.3 \\
\hline & No & 39 & 86.7 \\
\hline \multirow{2}{*}{ RD } & Yes & 44 & 97.8 \\
\hline & No & 1 & 2.2 \\
\hline $\mathbf{O}_{2}$ & Yes & 44 & 97.8 \\
\hline requirement & No & 1 & 2.2 \\
\hline \multirow{2}{*}{ Lethargy } & Yes & 27 & 60.0 \\
\hline & No & 18 & 40.0 \\
\hline Abdominal & Yes & 6 & 13.3 \\
\hline distension & No & 39 & 86.7 \\
\hline Feeding & Yes & 26 & 57.8 \\
\hline intolerance & No & 19 & 42.2 \\
\hline \multirow{2}{*}{ HSM } & Yes & 10 & 22.2 \\
\hline & No & 35 & 77.8 \\
\hline
\end{tabular}


Table (3):

\begin{tabular}{|c|c|c|c|c|c|c|c|c|}
\hline \multirow[t]{2}{*}{ Variable } & \multicolumn{3}{|c|}{$\begin{array}{c}\text { Study group } \\
(\mathrm{N}=\mathbf{4 5})\end{array}$} & \multicolumn{3}{|c|}{$\begin{array}{c}\text { Control group } \\
(\mathrm{N}=\mathbf{4 0})\end{array}$} & \multirow{2}{*}{$\begin{array}{c}\mathrm{Z}_{\mathrm{MWU}} \\
\text { test }\end{array}$} & \multirow[t]{2}{*}{$\boldsymbol{P}$} \\
\hline & Mean & \pm SD & Range & Mean & \pm SD & Range & & \\
\hline Blood glucose (mg/dl) & 144.9 & 56.6 & $45-260$ & 113.3 & 21.9 & $79-260$ & 2.64 & $0.008(\mathrm{~S})$ \\
\hline Hb (gm/dl) & 12.6 & 3.03 & $7.1-19.4$ & 16.0 & 1.47 & $13-19.5$ & $6.4 \dagger$ & $<0.001(\mathrm{HS})$ \\
\hline $\operatorname{PLTs}\left(\mathbf{x 1 0}^{3}\right)$ & 104.7 & $\begin{array}{c}83.4 \\
2\end{array}$ & $7-379$ & 312.1 & $\begin{array}{c}71.0 \\
8\end{array}$ & $202-614$ & 7.28 & $<0.001(\mathrm{HS})$ \\
\hline WBCs $\left(\times 10^{3}\right)$ & 16.1 & 8.27 & $3.3-31.6$ & 10.1 & 2.69 & $6.4-16.8$ & 3.05 & $0.002(\mathrm{~S})$ \\
\hline Total neutrophils & 63.5 & $\begin{array}{c}14.0 \\
8\end{array}$ & $23-87$ & 39.2 & 4.21 & $31-47$ & $\begin{array}{c}10.49 \\
+\end{array}$ & $<0.001(\mathrm{HS})$ \\
\hline $\begin{array}{l}\text { Immature } \\
\text { neutrophils }\end{array}$ & 15.1 & 3.67 & $7-26$ & 2.2 & .53 & $1-3$ & 8.06 & $<0.001(\mathrm{HS})$ \\
\hline I/T ratio & 0.24 & 0.04 & $0.2-0.36$ & 0.08 & 0.07 & $0.02-0.3$ & 6.79 & $<0.001(\mathrm{HS})$ \\
\hline Serum creatinine & 0.75 & 0.36 & $0.28-2.0$ & --- & ---- & --- & ---- & ---- \\
\hline Quantitative CRP & 40.3 & 33.9 & $6-96$ & --- & --- & --- & ---- & ---- \\
\hline Serum amyloid A & 38.8 & $\begin{array}{c}26.4 \\
5\end{array}$ & $0.2-81.7$ & 1.26 & 2.97 & $0.05-17.4$ & 6.95 & $<0.001(\mathrm{HS})$ \\
\hline
\end{tabular}

Table (4):

\begin{tabular}{lccc}
\hline & Variable & No. $(\mathbf{N}=\mathbf{4 5})$ & \% (100\%) \\
\hline No growth & & 10 & 22.2 \\
Gram positive & CONS & 6 & 13.3 \\
& Staph aureus & 3 & 6.7 \\
& GPS & 4 & 8.9 \\
\multirow{3}{*}{ Gram negative } & MRSA & 3 & 6.7 \\
& Klebsiella & 8 & 17.8 \\
& E Coli & 3 & 6.7 \\
& Pseudomonas & 7 & 15.6 \\
& Acinetobacter & 1 & 2.2 \\
\hline
\end{tabular}


Table (5):

\begin{tabular}{|c|c|c|c|c|c|c|}
\hline & & \multicolumn{4}{|c|}{ Group } & \multirow[t]{2}{*}{$\mathbf{X}^{2} \& \mathbf{P}$} \\
\hline & & & Cases & Controls & Total & \\
\hline \multirow[t]{6}{*}{ Death } & Yes & Count & 12 & 0 & 12 & 12.4 \\
\hline & & $\begin{array}{c}\text { \% within } \\
\text { Group }\end{array}$ & $26.7 \%$ & $.0 \%$ & $14.1 \%$ & $\begin{array}{c}\&<0.001 \\
\quad(\mathrm{HS})\end{array}$ \\
\hline & No & Count & 33 & 40 & 73 & \\
\hline & & $\begin{array}{l}\text { \% within } \\
\text { Group }\end{array}$ & $73.3 \%$ & $100.0 \%$ & $85.9 \%$ & \\
\hline & Total & Count & 45 & 40 & 85 & \\
\hline & & $\begin{array}{c}\text { \% within } \\
\text { Group }\end{array}$ & $100.0 \%$ & $100.0 \%$ & $100.0 \%$ & \\
\hline
\end{tabular}

Table (6):

\begin{tabular}{|c|c|c|c|c|c|c|c|c|}
\hline \multirow[t]{2}{*}{ Variable } & \multicolumn{3}{|c|}{ Died $(N=12)$} & \multicolumn{3}{|c|}{ Survived (N=33) } & \multirow{2}{*}{$\mathrm{Z}_{\mathrm{MWU}}$ test } & \\
\hline & Mean & \pm SD & Range & Mean & \pm SD & Range & & \\
\hline Serum amyloid $A$ & 53.8 & 19.3 & $12.5-81.0$ & 33.3 & 26.7 & $0.2-81.7$ & 2.53 & $0.011(S)$ \\
\hline
\end{tabular}

Table (7):

\begin{tabular}{ccccccccc}
\hline $\begin{array}{c}\text { Serum } \\
\text { amyloid } \\
\text { A }\end{array}$ & Sens\% & Spec\% & PPV\% & NPV\% & $\begin{array}{c}\text { Accuracy } \\
\%\end{array}$ & AUC & $\begin{array}{c}\text { 95\%CI of } \\
\text { AUC }\end{array}$ & $p$ \\
\hline$\geq 2.08$ & $86.7 \%$ & $85 \%$ & $86.7 \%$ & $85 \%$ & $85.9 \%$ & 0.939 & $0.89-0.99$ & $\begin{array}{c}<0.001 \\
(\mathrm{HS})\end{array}$ \\
\hline
\end{tabular}

Table (8):

\begin{tabular}{ccccccccc}
\hline $\begin{array}{c}\text { Serum } \\
\text { amyloid } \\
\text { A }\end{array}$ & Sens\% & Spec\% & PPV\% & NPV\% & $\begin{array}{c}\text { Accuracy } \\
\%\end{array}$ & AUC & $\begin{array}{c}\text { 95\%CI of } \\
\text { AUC }\end{array}$ & $p$ \\
\hline$\geq 45.2$ & $83.3 \%$ & $69.7 \%$ & $50 \%$ & $92 \%$ & $73.3 \%$ & 0.749 & $0.60-0.897$ & $\begin{array}{c}=0.011 \\
(\mathrm{~S})\end{array}$ \\
\hline
\end{tabular}




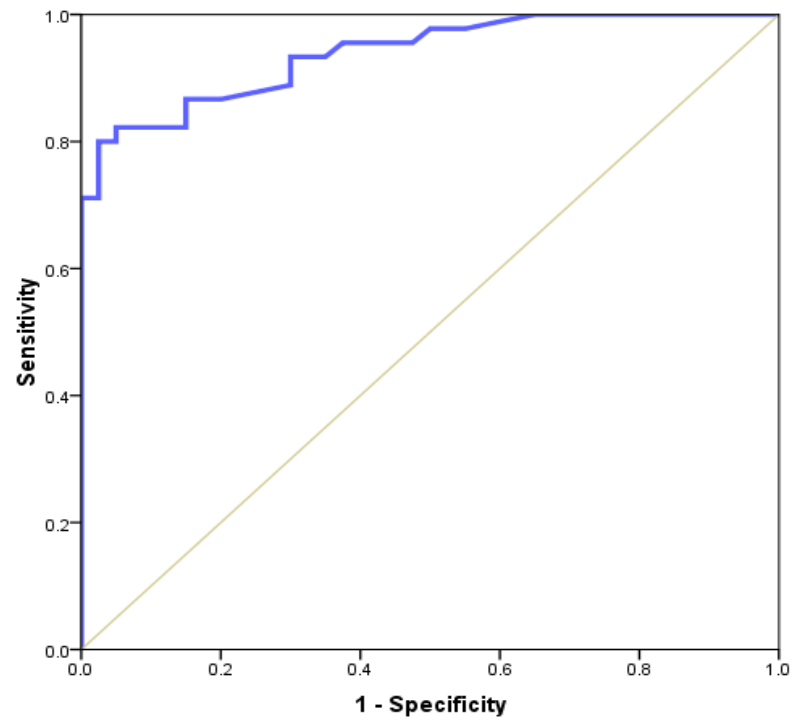

Fig. (1)

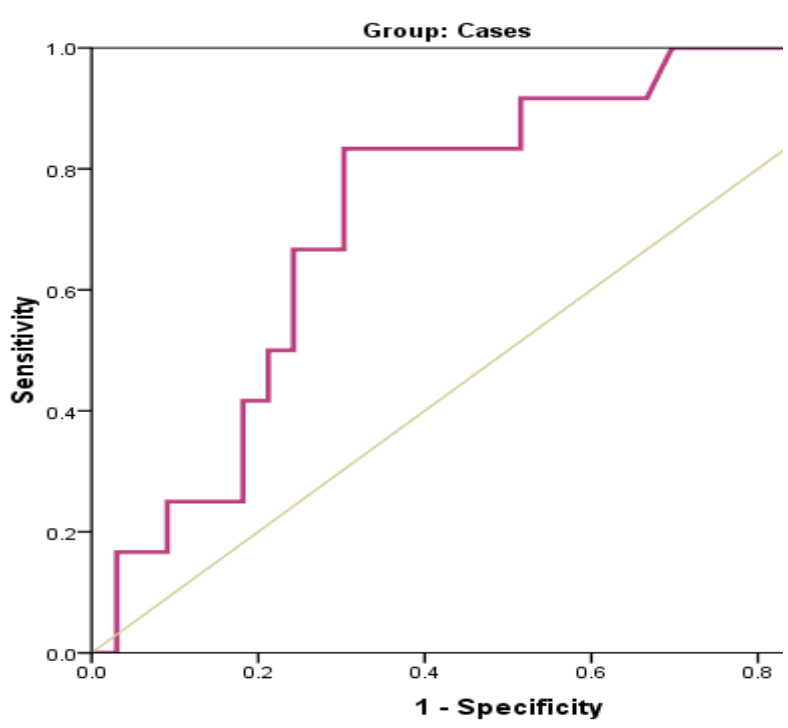

fig. (2)

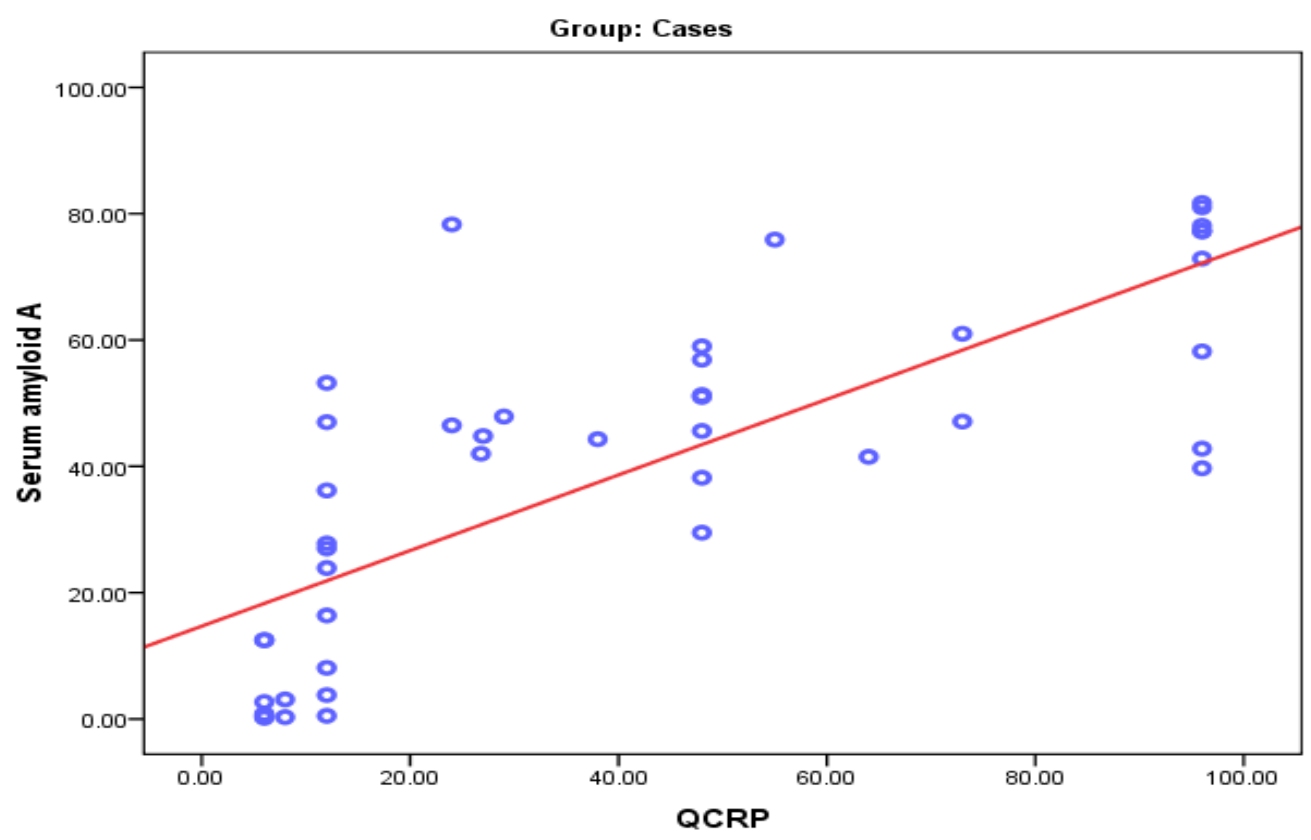

Fig. (3)

\section{Discussion:}

This study showed that, there was no statistically significant difference among sepsis and controls groups regarding age and sex. This study showed that, a predominance of males among patients with neonatal sepsis(60\%). This agree with Higazi et al (8) in their study to evaluate the diagnostic and prognostic performances of urinary interleukin-18 (uIL-18) and serum amyloid A (SAA) in neonatal sepsis parallel to $\mathrm{C}$ reactive protein. 
This study showed that, birth weight was significantly lower among sepsis group than control group, $p<0.05$.

This agree with El-Mashad et al (9) and found that, mean value of weight was significantly lower among sepsis than nonsepsis group $(p<0.05)$.

Low birth weight are at increased risk of LOS because of their underdeveloped immune systems, need for central venous access, and prolonged hospitalizations (10).

In our study, we found no significant difference between both groups regarding mode of delivery. This is in agreement with Abo Raya et al (11) who found the same results, but Stoll et al (12) ported that babies delivered by vaginal delivery were more likely to have EOS than those delivered by CS. This may be related to good sterilization and intrapartum chemoprophylaxis which dramatically decreased the risk of sepsis among neonates delivered by CS.

On clinical evaluation of the septic group RD, poor Moro, poor suckling and lethargy were the commonest clinical presentations of sepsis this comes in agreement with Shalaby et al

In the present study, we found that positive blood cultures were $77.8 \%$ and gram negative blood cultures were $22.2 \%$. Regarding the causative organisms, gram negative organisms were detected in $42.2 \%$ of patients,
Klebsiella represents the commonest gram negative organisms (17.8\%) followed by pseudomanus (15.6\%), Ecoli (6.7\%) and acinetobacter $(2 \%)$.

Gram positive organisms were detected in $35.6 \%$ of patients, CONS represents the commonest gram positive organisms (13.3\%) followed by GBS (8.9\%), then staph aureus and MRSA (6.7\%). This agrees with ElMashad et al (9), who aimed to evaluate serum leptin level in neonates with sepsis to aid early and accurate diagnosis and to provide an effective treatment. They found that, $23.3 \%$ had negative blood cultures and $76.6 \%$ of the case group (23 patients) had positive blood cultures; $36.7 \%$ of these were positive for Klebsiella spp., $16.7 \%$ were positive for Staphylococcus aureus, $13.3 \%$ were positive for Escherichia more Details coli, $6.7 \%$ were positive for $\beta$-hemolytic streptococci, and $3.3 \%$ were positive for Candida albicans (14), in which nearly half of the positive blood cultures grew K. pneumoniae.

Regarding $\mathrm{CBC}$, our results revealed that, there were significant increase in WBCs, immature neutrophils and I/T ratio among patients than controls and significant decrease in $\mathrm{Hb}$ and platelets among patients than controls. Mondal et al (15) who stated that low $\mathrm{Hb}$ level was due to increased hemolysis of red blood cells caused by bacterial infection in blood. 
In our study, the mean count of platelets in the sepsis group was significantly lowered compared with the controls. This agrees with Shalaby et al (1(13), who studied platelets in neonatal sepsis. They found statistically significant decrease in sepsis group than the control group.

Regarding, CRP was found significant increase in patients than controls. This agrees with Shalaby et al (13), who found increase in CRP level among confirmed sepsis group.

In the present study death was higher among cases group than controls group. This was in agreement with,Shalaby et al (16), who aimed to determine the levels of SAA protein in neonatal sepsis, to correlate SAA levels with $\mathrm{CRP}$, and to evaluate the role of SAA as a marker of neonatal sepsis. They found death was higher among neonatal sepsis than controls group.

The mean value of SAA in septic group was $38.8 \mu \mathrm{g} / \mathrm{ml}$ compared to $1.26 \mu \mathrm{g} / \mathrm{ml}$ in control group, with highly statistically significant increase in patients than controls $(p<0.001)$. This agrees with Higazi (8), who demonstrated that SAA was statistically significantly higher in septic neonates than in non-septic $\quad(\mathrm{p}<0.001)$ and there was statistically significant difference in the level of SAA between EOS and LOS groups in favor to $\operatorname{LOS}(p=0.02)$.
This study showed that, the mean value of SAA in dead cases was higher compared to control group. This was in agreement with, Shalaby et al (16) in their study on estimation of serum amyloid A in neonatal sepsis.

In our study ROC curve was done to show the performance of prediction of early diagnosis of LOS, we found that at a cut-off value of SAA $>2.8 \mu \mathrm{g} / \mathrm{ml}$, serum amyloid A had a sensitivity $86.7 \%$, specificity $85 \%$, PPV $86.7 \%$, and NPV $85 \%$ for early diagnosis of LOS. At a cut-off value of SAA $>45.2 \mu \mathrm{g} / \mathrm{ml}$, SAA had a sensitivity $83.3 \%$, specificity 69.7\%, PPV 50\%, and NPV 92\% for the prediction of mortality among late onset sepsis patients.

In a study done by Arnon et al (17), found a sensitivity 96\%, specificity 95\%, PPV $85 \%$, and NPV $99 \%$ at late onset of sepsis. Higazi et al (8), demonstrated that performance of serum amyloid $\mathrm{A}$ in prediction of late onset sepsis had a sensitivity $95.6 \%$, specificity 100\%, PPV 100\%, and NPV 98\%.

In a study done by Cetinkaya et al (18) to determine the role of serum amyloid A (SAA) in diagnosis of neonatal sepsis in comparison to CRP and PCT, it was found that, SAA is more sensitive (76.4\%), than Procalcitonin (PCT) $(74.8 \%)$ and CRP (72.3\%).

This study showed that, there was a statistically significant positive correlations between SAA and CRP among cases group. 
This agrees with Higazi et al (8), who demonstrated a statistically significant positive correlations between SAA and CRP among sepsis group.

Data from a meta-analysis $(n=823)$ revealed pooled sensitivity of $84 \%$, pooled specificity of $89 \%$ (6).

More widespread availability of this test kit may make SAA a more widely used marker for the diagnosis of NS. SAA may be of use in the early diagnosis of EOS (19).

\section{Conclusion:}

The high sensitivity, specificity, positive predictive value and negative predictive value of SAA protein could help the clinicians for early diagnosis of neonatal sepsis.

\section{References:}

(1) El-Din, S., Rabie, E. M., El-Sokkary, M. M. A., Bassiouny, M. R., \& Hassan, R. (2015). Epidemiology of Neonatal Sepsis and Implicated Pathogens: A Study from Egypt. BioMed research international, 2015, 509484

(2) Wang, X., Wang, X., Liu, X., Wang, X., Xu, J., Hou, S., et al (2015). miR-15a/16 are upreuglated in the serum of neonatal sepsis patients and inhibit the LPS-induced inflammatory pathway. International Journal of Clinical and Experimental Medicine, 8(4), 5683-5690.

(3) Bentlin, M. R., de Souza Rugolo, L. M. S., Junior, A. R., Hashimoto, M., \& Lyra, J. C.(2007)Is urine interleukin-8 level a reliable laboratory test for diagnosing late onset sepsis in premature infants? J Trop Pediatr. 53:403-408.
(4) Montagnana M\& Danese E. (2016):Red cell distribution width and cancer. Ann Transl Med.;4:399.

(5) Loonen, A. J., de Jager, C. P., Tosserams, J., Kusters, R., Hilbink, M., Wever, P. C., \& van den Brule, A. J. (2014). (Biomarkers and molecular analysis to improve bloodstream infection diagnostics in an emergency care unit. PLoS One. 2014;9:e87315. (6)Yuan, H., Huang, J., Lv, B., Yan, W., Hu, G., Wang, J., et al(2013): Diagnosis value of the serum amyloid A test in neonatal sepsis: a meta-analysis. Biomed Res Int.;:520294.

(7) Sucilathangam, G., Amuthavalli, K., Velvizhi, G., Ashihabegum, M. A., Jeyamurugan, T., \& Palaniappan, N. (2012): Early diagnostic markers for neonatal sepsis: comparing procalcitonin (PCT) and C-reactive protein (CRP). J ClinDiagn Res, 2012;6(627):31.

(8) Higazi, A. M., Mahrous, D. M., Sayed, S. Z., Mohamed, O. G., \& Aly, S. S. (2016) Assessment of Urinary Interleukin-18 and Serum Amyloid A Efficacies against C-Reactive Protein in Diagnosis and Follow-up of Neonatal Sepsis. J Clin Cell Immunol $7: 446$.

(9) El-Mashad, G. M., El-Sayed, H. M., \& Salem, O. H (2016): Serum leptin level as a marker of neonatal sepsis. Menoufia Med J [serial online] 2016 [cited 2017 Nov 7] ;29:252-8.

(10) Polin RA.(2008) systemic infection and brain injury in the preterm infant.JPediatr(Rio J):84:188-91.

(11) Abo Raya EMM, El-Defrawy MS, Hassan AAE and Tawfik N: (2012): Serum Neopterin as a Diagnostic Marker for Neonatal Sepsis. Thesis submitted to Faculty of Medicine, Benha University.

(12) Stoll, B. J., Gordon, T., Korones, S. B., Shankaran, S., Tyson, J. E., Bauer, C. R.,et al. 1996): Early-onset sepsis in very low birth weight neonates: a report from the National Institute of Child Health and Human Development Neonatal Research Network. The Journal a The Journal of pediatrics. 1;129(1):72-80. 
(13) Shalaby, M. M., Sobeih, A. A., Abdulghany, W. E., Behiry, E. G., Ismail, Y. M., \& Abd-El-Aziz, M. A. (2017). Mean platelet volume and serum uric acid in neonatal sepsis: A case-control study. Annals of Medicine and Surgery, 20, 97-102. http://doi.org/10.1016/j.amsu.2017.06.015

(14) Dzwonek, A. B., Neth, O. W., Thiébaut, R., Gulczynska, E., Chilton, M., Hellwig, T., et al. (2008)The role of mannose-binding lectin in susceptibility to infection in preterm neonates. Pediatr Res; 63:680-685.

(15) Mondal, S. K., Nag, D. R., Bandyopadhyay, R., Chakraborty, D., \& Sinha, S. K. (2012): Neonatal sepsis: role of a battery of immunohematological tests in early diagnosis. International Journal of Applied and Basic Medical Research.;2(1):43-47

(16)Krishnaveni, P., Vanitha, G. M., \& Pradeep, G. C.
M. (2016). Estimation of serum amyloid A protein in neonatal sepsis: a prospective study. International Journal of Medical Science and Public Health, 5(8), 1665-1673.

(17)Arnon, S., Litmanovitz, I., Regev, R. H., Bauer, S., Shainkin-Kestenbaum, R., \& Dolfin, T. (2007). Serum amyloid A: an early and accurate marker of neonatal early-onset sepsis, J Perinatol , 27; 297-302.

(18) Cetinkaya, M., Özkan, H., Köksal, N., Celebi, S., \& Hacımustafaoğlu, M. (2009):Comparison of serum amyloid A concentrations with those of C-reactive protein and procalcitonin in diagnosis and follow-up of neonatal sepsis in premature infants. J Perinatol; 29 (3): 225-31.

(19) Gilfillan, M., \&Bhandari, V. (2019).Neonatal sepsis biomarkers: where are we now?. Research and Reports in Neonatology, Volume 9; 9-20.

To cite this article: Heba M. Abd Elkhalek, Neeven T Abed, Omima M. Abdel Haie, Seham Goda. Role of Serum Amyloid A Protein in the Early Detection of Late Onset Sepsis in Neonates. BMfJ 2019;37(1):155-168. DOI: 10.21608/bmfj.2020.18739.1139 